\title{
ALGUNS PRESSUPOSTOS LIBERAIS DA FILOSOFIA DO DIREITO DE HEGEL E OS ELEMENTOS CENTRAIS DA CRÍTICA DO JOVEM MARX
}

\author{
Eloi Pedro Fabian ${ }^{1}$
}

\begin{abstract}
Resumo:O artigo procura identificar e refletir sobre alguns pressupostos da obra hegeliana que fundamentam o liberalismo político, quanto a dupla limitação entre Direito e Moralidade, assim como, suas consequências para a concepção de Estado e Sociedade. Num segundo momento, procura analisar a crítica de Marx à Filosofia do Direito de Hegel sob o ponto de vista dos limites interpretativos do jovem pensador com relação ao seu pai intelectual - Hegel, no que diz respeito a não compreensão dessa estratégia e necessidade teórica de dupla limitação entre Direito e Moral. O artigo ainda defende que a inversão dialética do ideal para o real pretendida pelo filósofo de Trier deve ser interpretada como expressão de uma relação de amor-ódio teórico entre Marx e Hegel.
\end{abstract}

Palavras-chave: Filosofia. Estado. Moral. Direito. Liberalismo.

Abstract:The article seeks to identify and reflect on some assumptions of the Hegelian work that underlies the political liberalism, as the dual boundary between Law and Morality, as well as their consequences for the design of State and Society. Secondly, analyzes Marx's critique of Hegel's Philosophy of Right from the point of view of the interpretative boundaries of the young thinker with respect to its intellectual father - Hegel, in regards to the no understanding of the strategy and theoretical need for double boundary between law and morals. The article argues that the dialectical inversion of the ideal to the real philosopher of Trier intended to be must be interpreted as an expression of a theoretical love-hate relationship between Marx and Hegel.

Keywords: Philosophy. State. Moral. Right. Liberalism.

\section{INTRODUÇÃ̃}

Nos Princípios da Filosofia do Direito, Hegel leva com radicalidade a ideia da liberdade universal já pressuposta nas obras anteriores. Esta obra pretende que a liberdade fique transparente objetivamente enquanto algo decorrente do sistema e que se traduza na realphilosophie. Para isso teve que adotar o caminho metodológico da dupla limitação entre direito e dever. O direito suprassumindo a moralidade e o Estado por sua vez, suprassumindo as demais esferas da sociedade. Essa estratégia da dupla limitação acaba por desenhar a ideologia do liberalismo na medida em que o direito não consegue interferir em questões, por exemplo, cuja vontade livre não esteja pressuposta. E isso significa, em última análise, que nem tudo que pertença ou que esteja previsto legalmente é, necessariamente, moralmente justo.

Se por um lado a Filosofia do Direito de Hegel apresenta aspectos liberais ocultos em

\footnotetext{
${ }^{1}$ Doutor em Filosofia pela PUC-RS. Professor adjunto III da Universidade Fronteira Sul - Erechim. Contato: eloi.fabian@uffs.edu.br
} 
sua pretensão, ao mesmo tempo ela nos permite visualizar o seu potencial crítico ao avesso. Isto é possível se conseguimos compreender o conflito que ela mesma está instaurando no direito, na ética e na política moderna.

Conferindo alguns temas e dimensões da crítica de Marx à obra hegeliana é certo que o pensador de Trier não aceita a forma de limitação entre liberdade universal e particular. Caindo nas armadilhas interpretativas dos jovens hegelianos, Marx parece não perceber a necessidade lógica e metodológica da Filosofia do Direito, enquanto uma exposição plena do princípio de liberdade universal que vinha acompanhando todas as obras de Hegel. Logo, seu interesse dirige-se à descoberta dos fundamentos concretos desta sociedade enquanto pressupostos desaparecidos da 'superfície'. Apesar de seu respeito à Hegel e sua Filosofia do Direito, Marx critica os parágrafos da obra (parágrafos 261 a 313), cuja temática trata do Poder Político Interno. Denuncia ali o predomínio da ideia teórica sobre as estruturas reais da sociedade (família, sociedade civil). O que significa, na verdade, traduzir numa linguagem mais objetiva o que Hegel estava por descrever.

O propósito deste artigo é trazer alguns pressupostos da Filosofia do Direito de Hegel a partir da crítica de Marx a esta obra, efetuada por volta de 1843, e que fora reconhecida como a primeira grande obra do filósofo de Trier. Priorizaremos aqui a tese central de que Hegel não abandona o projeto de liberdade universal em sua Filosofia do Direito, mesmo que para isso acabe desenhando uma concepção liberal de Estado. Por outro lado, tentaremos expôr Marx como um teórico buscando rejeitar a estratégia metodológica de Hegel.

\section{Alguns Núcleos da Filosofia do Direito de Hegel: pressupostos para a crítica de Marx.}

Preocupado em tornar inteligível os processos históricos de sua época, principalmente a partir dos dois grandes acontecimentos que marcaram a Europa no Séc. XVIII, a saber, a Revolução Francesa e a Declaração dos Direitos Humanos, Hegel irá buscar uma formulação teórica compatível com esses fatos. Juntamente com os seus colegas Schelling e Hölderlin, o filósofo inclina-se na tarefa de criar um movimento intelectual pertinente a fim de trazer o espírito do seu tempo para dentro do mundo intelectual, com duas intenções principais: a) garantir o projeto de liberdade humana previsto em seu modelo filosófico; e b) propiciar a legitimação teórica desses fatos históricos importantes para a época.

No conjunto da produção intelectual de Hegel visualiza-se ainda em 1797 algumas preocupações básicas em torno de uma filosofia política compatível com seu momento histórico. Em dois escritos (Constituição da Alemanha e Assembleia dos Estados de 
Württenberg ${ }^{2}$ ) Hegel introduz os traços fundamentais de sua compreensão política que o acompanharão em seus trabalhos posteriores, culminando com a Filosofia do Direito.

Previamente, ao tentar esboçar alguns núcleos temáticos sobre os Princípios da Filosofia do Direito é importante, mesmo que de modo limitado, localizar a obra no conjunto sistemático. Inicialmente cabe mencionar um traço pressuposto de suma importância na compreensão de toda filosofia hegeliana. A ideia de liberdade é o motor interno de filosofia porque o próprio critério de desenvolvimento do Espírito é a sua auto-liberação. No começo da estruturação sistemática de Hegel, por volta de 1806, o tema do reconhecimento é central para se compreender a necessidade do pressuposto da liberdade. Logo na Fenomenologia do Espírito, se pudéssemos designá-la como a primeira etapa do sistema, enquanto 'ciência da experiência da consciência', a exposição hegeliana apresenta a ideia de que "a ciência só se permite organizar mediante a própria vida do conceito" (HEGEL, 1992, p. 50). Por isso, o Espírito tem de captar e expressar o verdadeiro não como substância, mas como, e ao mesmo tempo, seu próprio sujeito livre.

Mencionada a obra inicial dessa sistematização com seus pressupostos de liberdade, podemos seguir afirmando que, posteriormente, na Ciência da Lógica, tomada como a segunda etapa sistemática, em que o 'processo do pensar quer tornar-se a si mesmo como pensante', Hegel continuará expondo amplamente esse pressuposto da liberdade através da explanação do surgimento das categorias, desde sua abstração até sua concretude, alcançando a Ideia Absoluta. Por fim, na terceira etapa, em que Hegel se preocupa com as exigências sistemáticas de sua filosofia em relação às diferentes realidades, é que a obra Princípios $d a$ Filosofia do Direito surge. Ela constitui-se no lugar privilegiado da ideia de liberdade na medida em que o Espírito está encarregado de realizar essa liberdade objetivamente. Aqui o pensamento pretende tornar-se transparente na realidade. É como que uma tentativa de trazer à tona a noção de liberdade que a própria sociedade moderna possui. Por essa razão, há uma fonte de polêmica nas interpretações sobre a obra, relativamente no que diz respeito à compatibilidade entre as exigências do modelo sistemático e a realidade. Uma questão se impõe: como é possível compreender esse processo da relação entre as determinações ideais e as determinações reais? Como é possível afirmar que o conceito e seu pressuposto de liberdade é capaz de traduzir fielmente a própria realidade?

A propósito de melhor esclarecimento sobre o lugar da Filosofia do Direito no sistema

\footnotetext{
${ }^{2}$ Cf. ROSENFIELD, D. Introdução ao pensamento político de Hegel. São Paulo: Ática, 1993, p. 26. Nesse trabalho há uma interessante exposição das raízes do pensamento político de Hegel e do surgimento de seu conceito de Estado.
} 
hegeliano, insistimos nessa tarefa de visualizar parcialmente o conjunto de determinações hegelianas para assim posicionar a obra. Genericamente, pode-se dizer que, para Hegel, a determinação imediata do espírito subjetivo é a alma, cujo tema principal é a antropologia. Nesse contexto se expõe o caminho que a alma percorre, mesmo que ainda presa nas determinações naturais até alcançar uma relação com a corporeidade, permitindo diferenciarse em relação com a natureza. Passado esse processo surge a segunda dimensão do espírito subjetivo - a consciência. A partir do trabalho da Fenomenologia, a consciência, inicialmente como certeza sensível, formal e sem conteúdo, se eleva à autoconsciência na medida em que se toma a si mesma como objeto. Nesse meio termo, a autoconsciência passa desse enfrentamento com a consciência para uma unidade que se converte no concreto ser-por-si do eu - a razão (psicologia). Por fim, ao reconhecer a razão (Lógica) como fez com a consciência e autoconsciência, o Espírito se compreende como Espírito prático, isto é, como Espírito objetivo. É assim, nessa posição que podemos visualizar a Filosofia do Direito, enquanto ponto de chegada do processo iniciado no Espírito Subjetivo.

A Filosofia do Direito pode ser descrita como uma filosofia prática na medida em que representa o desenvolvimento da ideia da liberdade. Trata-se de uma 'Ciência Filosófica do Direito' e não de uma simples Ciência do Direito ${ }^{3}$. Com ela alcança-se o ponto em que a vontade deixa de estar encerrada na subjetividade auto-referente para determinar-se em sua objetividade nas Instituições. Portanto, a Filosofia do Direito irá localizar-se no momento do Espírito Objetivo no sentido de impor a ideia de liberdade ou de experimentar as condições objetivas de sua manifestação. Essa ideia o próprio Hegel tratou de explicitar na Introdução da obra ao afirmar que a Filosofia do Direito não é uma filosofia fundadora, pois o princípio de liberdade já está pressuposto nas determinações teóricas anteriores. O papel que a Filosofia do Direito cumpre é o de ser a expressão objetiva dessa liberdade. Conforme Hegel,

A ciência do direito é uma parte da filosofia. Deve, portanto, desenvolver a partir do conceito, a Ideia como aquilo que constitui a razão de um objeto, ou o que é o mesmo, observar o próprio desenvolvimento imanente da coisa mesma (HEGEL, 1988 , p. 56, § 2).

A obra política de Hegel também pode ser descrita enquanto uma tentativa de fazer uma síntese crítica da teoria política clássica, das construções do direito natural moderno, da economia política inglesa e da filosofia moral kantiana. Com esse esboço geral buscando localizar a Filosofia do Direito no conjunto teórico hegeliano, partiremos para uma tentativa de traçar algumas linhas básicas da obra, objetivando uma visualização mais precisa das

${ }^{3}$ Cf. WEBER, T. Hegel: Liberdade, Estado e História. Petrópolis: Vozes, 1993, p. 46. 
razões e motivos para a Crítica a Filosofia do Direito de Hegel elaborada por Marx.

Mesmo com tantas controvérsias com relação à interpretação a Filosofia do Direito apresenta uma habilidade peculiar quanto sua capacidade de abarcar e determinar a totalidade do conjunto da sociedade moderna (relação entre esferas particulares e universais, instituições, direitos e deveres, moralidade e legalidade). A obra apresenta um magnífico esforço em manter uma coerência metodológica e capacidade de explicar concretamente as formas e instituições da sociedade moderna de tal forma que assegure e concretize seu princípio pressuposto de liberdade universal. A partir dessas afirmações torna-se evidente duas consequências interpretativas básicas que deverão ficar explícitas no decorrer dessa exposição: a) a primeira refere-se à ideia da Filosofia do Direito de 1821 possuir subjacentes traços do liberalismo político; b) a segunda diz respeito aos limites do jovem Marx e dos demais jovens hegelianos ao criticar seu pai intelectual, por não ter percebido o papel metodológico da referida obra, enquanto teoria construtiva-idealista que não está fundada no uso meramente afirmativo da ideia de liberdade.

Quanto à sua estrutura geral, a Filosofia do Direito apresenta três importantes partes: Direito Abstrato, Moralidade e Eticidade (Família, Sociedade Civil e Estado). Com a pretensão de tornar transparentes as conotações que o termo de liberdade assume na sociedade moderna, através das formas institucionalizadas (direito, ciência do Estado, etc...), a obra começa com um conceito abstrato (vazio) de liberdade que vai se 'preenchendo' no decorrer da sua construção, através das determinações objetivas da sociedade. Parte-se de uma ideia metafísica de liberdade (individual) que vai se plenificando, até tornar-se efetiva (universal).

Nas páginas iniciais da Filosofia do Direito é possível deparar-se como um problema central, o qual Hegel não poderia deixar de enfrentar, justamente por buscar fazer transparecer na obra uma objetividade e concretude da ideia de liberdade universal. Trata-se da abordagem da relação entre a ideia de efetividade (Wirklichkeit) e a racionalidade, expressa no prefácio, através da seguinte frase: “o que é racional é real e o que é real é racional” (HEGEL, 1988, p. 51). No fundo, a frase pretende esclarecer a necessidade de comprovação objetiva dessa ideia de liberdade. Uma vez apresentada, a afirmação pode ser considerada uma das passagens que mais tenham provocado ambiguidades interpretativas. Dependendo do modo como a mesma é abordada, ela pode gerar uma noção de legitimação ou processo, ou fluxo dialético. O jovem Marx já percebera isto ao vaticinar:

A direita hegeliana priorizou o segundo momento da frase para justificar a racionalidade do real, entendida por eles como a sociedade e o Estado prussiano onde viviam. Os jovens contestadores, por sua vez, preferiram enfatizar o 
racional para contrapô-lo às mazelas da realidade, para mostrar que o momento da racionalidade ainda não tinha chegado e que ele só se efetivaria mediante a negação do existente e toda a sua gritante irracionalidade (MARX, 1995, p. 23).

A linha interpretativa de comentaristas consultados para esta elaboração nos permitiu perceber uma amplitude e um maior dimensionamento do reducionismo apresentado pelos interpretes que legitimam o real pela Filosofia do Direito de Hegel. Nessa perspectiva, a proposição do prefácio da obra é tomada como expressão de um pressuposto metodológico necessário para Hegel. Ou seja, esse pressuposto prioriza a ideia de que a realidade deve seguir um caminho racional efetivo e contínuo. Há, portanto, uma noção de processo e de efetividade (Wirklichkeit) que rompe com uma noção legitimadora e estática. De acordo com ROSENFIELD, se optamos por uma interpretação estática da passagem do prefácio da Filosofia do Direito, acima referida

\footnotetext{
o pensamento de Hegel encontra-se aqui reduzido a um pensamento que legitimaria a evolução do mundo, isto é, a sua ordem. Um pensamento que não conseguiria atravessar os véus do real e não se perguntaria sobre o movimento do aparecer. Hegel, ao contrário, pretende ser um pensador da evolução do mundo como processo de totalização reflexiva; processo que busca a razão de ser do que é, através deste duro trabalho que consiste em liberar seu fundamento essencial, que não se confunde com a ordem empírica do mundo (1983, p. 17).
}

A frase, se tomada numa perspectiva de base legitimadora da realidade, estaremos consequentemente, afirmando o desmembramento das obras iniciais de Hegel com sua Filosofia do Direito, uma vez que se perde o horizonte sistemático pressuposto, relativo a ideia de liberdade enquanto princípio universal. Para FLICKINGER, a frase, que aparentemente é uma tautologia, é na verdade, uma expressão do próprio método hegeliano. Trata-se da ideia de que "a ciência filosófica tem de pressupor a validade objetiva da razão, isto é, de sua ideia princípio para conseguir descobrir a lógica interna da constituição de seu objeto em questão" (1989, p. 34). Não se trata, portanto, da mera aceitação de nossa realidade político-social enquanto objetivação da ideia de liberdade.

Outro aspecto importante da Filosofia do Direito de Hegel está presente na Introdução. Ali Hegel tratará de demonstrar que o âmbito do direito representa a vontade livre na forma como ela se realiza. De acordo com o quarto parágrafo, a vontade livre é o ponto de partida do direito:

O terreno do direito é o espiritual; seu lugar mais preciso e seu ponto de partida é a vontade, que é livre, de modo tal que a liberdade constitui sua substância e determinação, e o sistema do direito é o reino do direito realizado, o mundo do espírito que se produz a partir de si mesmo como segunda natureza (HEGEL, 1983, p. 17). 
A liberdade é uma realização da vontade humana, a qual tem sua origem na razão (Espírito). Essa vontade livre, que é o fundamento do direito, se apresenta ainda como vontade subjetiva, que precisa aos poucos tornar-se objetiva. De espírito subjetivo irá tornarse um espírito objetivo. Para percorrer esse caminho Hegel iniciará com a exposição sobre o Direito Abstrato.

\section{A Estrutura da Filosofia do Direito}

\section{Direito Abstrato}

"Em seu conceito abstrato, a vontade livre em e por si, está na determinação da imediatez" (HEGEL, 1988, p. 65, § 4). Assim o autor inicia a exposição do Direito Abstrato. Trata-se de um primeiro passo em que sistematiza as formas de relacionamento imediato entre as pessoas, transformando as relações diretas interpessoais em relações juridicamente determinadas. Há uma preocupação em apresentar as formas concretas e imediatas da realização da ideia de liberdade e que passaremos a expor brevemente na sequência.

Segundo Hegel, para o homem moderno não é mais possível aspirar pertencer imediatamente ao âmbito universal da sociedade. Contrariamente à concepção da Pólis grega, para o homem moderno é necessário estabelecer os limites sob os quais ele possa desenvolver sua dimensão e seu 'espaço' individual. Nesta perspectiva, o Direito Abstrato, segundo Hegel, tratará de demonstrar de onde é derivada a ideia de vontade livre e, ao mesmo tempo, expor a estrutura racional das formas imediatas da vontade livre ao nível das instituições. Inicialmente, sendo abstrata, indeterminada e vazia, essa vontade livre se apresenta sem nenhuma mediação social. "O direito abstrato e, portanto, só uma mera possibilidade e por isso, algo formal frente a totalidade da situação (...). O direito é, em primeiro lugar, a existência imediata que se dá à liberdade de um modo também imediato" (HEGEL, 1988, p. $105-5, \S \S 37,40)$. Ainda não é possível visualizar nessa esfera, nada além de uma liberdade subjetiva.

A segunda parte desta citação a pouco referida traz implícita a importante noção de 'pessoa de direito'. Um termo jurídico que conota a possibilidade do indivíduo pertencente e ser possuidor de vontade. Trata-se de uma primeira manifestação mais abstrata e indeterminada de que todas as pessoas são portadoras de direitos e deveres e uma primeira aproximação das estruturas jurídicas, através da análise do relacionamento entre as pessoas, de modo particular. Como implicação dessa noção, neste relacionamento deveria ocorrer a delimitação entre os direitos mútuos em vista da distribuição justa das coisas materiais. 
Porém, "as formas chamadas abstratas do direito ainda não são capazes de refletir as instituições mediatizadoras desta liberdade em nível sociopolítico, nem a responsabilidade individual pela sua validade objetiva" (FLICKINGER, 1989, p. 36). Isto porque a imediatez e a indeterminação caracterizam esta esfera de relacionamento interpessoal da qual trata o Direito Abstrato.

Enquanto 'pessoa de direito' o indivíduo busca alcançar objetivamente todas as suas pretensões, tendo como pressuposto a ideia de liberdade e vontade livre. Nesta direção, é inevitável o surgimento da questão da propriedade. Conforme Hegel,

a pessoa, para existir como ideia, precisa dar para sua liberdade uma esfera exterior. Posto que a pessoa é a vontade infinita existente em e por si, em sua primeira determinação ainda totalmente abstrata, ou diferente dela, que pode constituir a esfera de sua liberdade, se determina ao mesmo tempo, como o imediatamente distinto e separável (HEGEL, 1988, p. 107, § 41).

A pessoa deve concretizar a sua interioridade livre numa exterioridade que the seja correspondente. O domínio da natureza parece ser um dos requisitos da realização da liberdade. Surge assim, o processo de abstração contínuo da base material - o objeto de negociar das pessoas. A propriedade, portanto, pode ser referida como o ser-aí da liberdade. Dessa questão da propriedade Hegel irá desdobrar mais alguns temas importantes como: a tomada de posse, o uso da coisa, a alienação da propriedade, o contrato, entre outros, que são consequência da descoberta por parte desse indivíduo, o de ser uma 'pessoa de direito'.

Aqui é importante visualizarmos o argumento principal do Direito Abstrato e algumas de suas implicações. No momento da apropriação de algum bem as pessoas adquirem objetos, os quais apresentam dois valores: a) valor de uso; b) valor de troca. No caso da posse enquanto direito de uso, o processo se realiza segundo a qualidade do objeto que procura responder as necessidades do dono. Já no caso da troca, no negócio juridicamente chamado de contrato, há uma definição a partir do valor do objeto em questão. Então, nesse segundo caso, o direito entra em ação para propiciar a justiça entre as partes, através do mencionado contrato. Nesse contexto, é importante lembrar, que começa a surgir implicações ou o implícito desenvolvimento das noções liberais do direito, enquanto o garantidor do pressuposto da vontade livre. Assim,

na medida em que as pessoas insistam na livre negociação, enquanto campo por excelência da realização da liberdade, o objeto de debate é o de conseguir consenso entre os parceiros. Na verdade, não interessa, em primeira linha, o objeto materialqualitativo da negociação, senão a livre aceitação do negócio (HEGEL, 1988, p. $107, \S 41)$.

A citação torna compreensível a interferência do direito para garantir o consenso entre 
as partes em negociação, cujo pressuposto é a vontade livre. Ainda estamos no âmbito da validade relativa entre os parceiros. Portanto, quando o assunto foge da alçada do pressuposto de liberdade o Direito demonstra-se incapaz de atuar e garantir a justiça entre as partes. A transição para a Moralidade será marcada pelo reconhecimento dos direitos da subjetividade através das relações sociais concretas que terão, posteriormente no Estado, o seu lugar enquanto instância universal.

\section{Moralidade}

A moralidade compreende a segunda parte da Filosofia do Direito de Hegel que tratará de introduzir uma expressão muito importante como: 'direito da vontade moral objetiva'. A moralidade é o nível da fundamentação da relação entre a vontade pessoal e a sua responsabilidade pelo bem comum. É da relação tensa entre esses dois elementos que surgem os deveres. A problemática hegeliana, posta neste contexto, é basicamente a seguinte: como resolver o conflito entre o meu direito e a imposição de deveres levando em conta as determinações jurídicas?

Na moralidade encontramos a explicitação do momento do retorno para a interioridade que ficava, ao mesmo tempo, delimitada e excluída pelo Direito Abstrato. Nela há a demonstração do âmbito da moralidade subjetiva enquanto uma instância mais elevada. Em relação ao momento anterior, a moralidade tem a tarefa de demonstrar o caráter essencial que possui a vontade individual para que as determinações do Direito Abstrato sejam efetivamente determinações da liberdade. Recorrendo ao texto hegeliano encontraremos, no início do capítulo sobre a Moralidade: "o ponto de vista moral é o ponto de vista da vontade enquanto não é meramente em si senão por si infinita" (HEGEL, 1988, p. 171, §105). Há uma transição do estritamente subjetivo para a objetividade.

Com a pretensão de demonstrar as limitações do Direito Abstrato, a Moralidade buscará a progressiva subjetivação do imediato e exterior, fazendo a liberdade aparecer como o que é por seu próprio conceito e autodeterminação. Neste particular, Hegel dialoga com a tradição da filosofia política moderna, em particular com Kant no que diz respeito sua filosofia moral, defendendo que a moralidade necessita de sua determinação, saindo da abstração para a objetividade que se efetiva nas Instituições. Hegel objeta o formalismo kantiano quando sentencia: "Com efeito, a proposição: 'considera se tua máxima pode ser tomada com princípio universal' seria muito boa se já dispuséssemos de princípios determinados sobre o que há que fazer" (HEGEL, 1988, p. 199, § 105). O problema em 
relação à filosofia moral de Kant, segundo Hegel, parece ser mesmo a falta de conteúdo e a separação entre Moral e Direito. Para isso, Hegel se esforçará em demonstrar que a moralidade precisa adquirir sua validade objetiva, incorporada nas instituições sociais.

Retomando o questionamento inicial sobre o conflito entre direitos e deveres, é importante mencionar o $\S 114$ da Moralidade. A expressão 'direito da vontade moral subjetiva' nos fornece algumas pistas da solução encontrada por Hegel à questão da relação direito/dever. No referido parágrafo Hegel afirma: "o direito da vontade moral contem os três seguintes aspectos: a) o direito abstrato ou formal da ação...; b) o particular da ação é seu conteúdo interior...; c) Este conteúdo, em quanto interno, elevado ao mesmo tempo a sua universalidade" (HEGEL, 1988, p. 178). Nessa passagem o filósofo busca dar uma resolução a essa tensão entre os meus direitos e a imposição dos deveres. Acompanhando a evolução do texto veremos que a solução encontrada é a da total submissão da moral ao direito e da moralidade à legalidade. Esse é o caminho encontrado por Hegel para resolver a tensão entre particular e universal, e ao mesmo tempo, preservando o pressuposto da liberdade universal.

A distinção entre moralidade e direito nos termos da abordagem da filosofia política, e algo que vem dos gregos. A moralidade ocupa o lugar do agir consciente do homem não submetido as regras formais. Já o direito baseia-se na lei formal sem uma preocupação com as conveniências sociais. Por uma necessidade metodológica e com o objetivo de garantir a continuidade de seu pressuposto ou princípio de liberdade para sua filosofia, Hegel irá submeter a moral ao direito. Neste sentido, acaba por diferenciar-se da tradição antiga, como lembra no $\S 118$. Desse modo, com a subordinação da moral ao direito começa a se configurar consequências em favor de uma ideologia liberal, que aparentemente não vinham à tona.

A partir da submissão da moral ao direito, Hegel acaba por postular que "o homem moderno, ao contrário, teria todas as condições de desresponsabilizar-se de efeitos objetivos não resultantes de sua vontade livre, restringindo, assim, a sua responsabilidade aos limites do próprio princípio fundamentador do direito liberal" (FLICKINGER, 1989, p. 37). Nesta direção, Hegel utilizará a expressão 'direito da vontade moral subjetiva' para descrever a postulação da situação do indivíduo na esfera da moralidade. O significado de tal expressão aponta que o direito acaba por abarcar e suprassumir a própria moralidade, e que o seu alcance objetivo só consegue assegurar ou controlar a validade universal dos fatos ou casos em que existe como pressuposto a vontade livre.

É possível utilizar o exemplo do comércio de um produto para explicitar essa noção. O direito trata de dar legitimidade a essa venda por se tratar da vontade livre do proprietário de 
desfazer-se de algo. Contudo, esse mesmo direito não tem interesse em tratar do grau de justiça desse ato de venda, bem como, do bem que está sendo negociado. Assumindo esse caminho de interpretação, tornam-se perceptíveis inúmeras lacunas da limitação do direito nas questões sociais se tivermos como utopia a legal e justa responsabilidade de uma ação. Nesse sentido, é que se pode afirmar sobre o problema da estratégia hegeliana em limitar a moralidade à legalidade, com o fim de garantir a liberdade universal.

O que marca a transição da Moralidade para a Eticidade é a descoberta de que o bem abstrato e a consciência moral elevados à totalidade, são em si idênticos com o âmbito em que encontram a verdade. A liberdade começa a adquirir a forma do conceito - liberdade como a auto-realização, então temos a esfera da Eticidade.

\section{Eticidade}

A Eticidade corresponde à última parte da Filosofia do Direito de Hegel. É a culminação de todo o processo anteriormente traçado e, portanto, só é possível a partir das esferas anteriores, uma vez que metodologicamente, para Hegel, o superior só pode ser resultado de um processo. Trata-se, basicamente, "das condições institucionais da incorporação da vontade livre particular no relacionamento complexo da vida social e política” (FLICKINGER, 1989, p. 35). Na Eticidade, Hegel irá expor a total objetivação da ideia da liberdade, na medida em que esta liberdade vai penetrando progressivamente da instituição básica (família) até a mais elevada esfera de universalidade (Estado). O conceito de Eticidade "permite a Hegel atualizar a unidade da subjetividade moral e da objetividade do direito porque, nela, a substância manifesta, enfim, em seu movimento de liberdade" (ROSENFIELD, 1983, p. 135).

O social é o verdadeiro lugar e a única realidade existente, em que os momentos anteriores podem ter vida. É o verdadeiro lugar no qual deve realizar-se as exigências da liberdade, onde o indivíduo pode alcançar a sua finalidade e chegar a sua auto-realização. Em seu comentário introdutório à tradução da obra hegeliana, VERNANT expõe essa perspectiva, na seguinte ideia: “enquanto que as duas primeiras partes (Direito Abstrato e Moralidade) expressam a divisão que surge no mundo moderno entre legalidade e moralidade, a terceira (Eticidade) deve mostrar, além de seu caráter de fundamento daquelas, a possibilidade da realização da unidade de um ethos" (1988, p. 24).

A definição de Eticidade dada por Hegel no início do capítulo descreve bem o seu significado enquanto momento que apresenta a totalização, tanto da subjetividade, quanto da objetividade. 
A eticidade é a ideia da liberdade como bem vivente que têm na autoconsciência seu saber, seu querer e, por meio de seu atuar, sua realidade; atuar que tem por sua vez no ser ético o seu fundamento em e por si e seu fim motor. É o conceito da liberdade que se tornou mundo existente e natureza da autoconsciência (HEGEL, 1988, p. 227).

Inúmeras e importantes são as passagens que se desdobram na Eticidade, porém, consideramos importante para nossos propósitos, centrarmo-nos no $\S 155$, um dos mais importantes para a compreensão da principal problemática do capítulo: o problema em identificar o princípio da unidade que rege a sociedade civil à unidade do Estado, enquanto base objetiva desta identificação. No referido parágrafo, Hegel dirá: "Nessa identidade da vontade universal e particular coincidem, portanto, o dever e o direito. Por meio do ético o homem tem direito na medida em que tem deveres, e deveres na medida em que tem direitos" (HEGEL, 1988, p. 227). Essa dupla limitação entre direito e deveres, conciliação entre o particular e o universal, é abordado também no $§ 261$, contexto de exposição sobre o Direito Político Interno, aliás, este é exatamente o parágrafo que Marx inicia sua crítica.

Através desta estratégia de dupla limitação entre direito e dever, Hegel procura garantir a manutenção do princípio de liberdade do indivíduo. A moralidade estará reduzida à base legal que tratará de interferir em todos os casos em que o pressuposto presente seja a vontade livre do indivíduo. A moralidade estará reduzida à base legal que tratará de interferir em todos os casos em que o pressuposto presente seja a vontade livre do indivíduo. Consequentemente o Estado terá de aceitar o papel do Direito Liberal, enquanto critério das exigências impostas aos cidadãos. O papel específico do Estado será de garantir que o direito instituído seja respeitado.

Numa leitura e análise mais detida da citação hegeliana a pouco apresentada, permite perceber algumas consequências para uma fundamentação liberal, bem como, algumas lacunas que a redução da moralidade à legalidade implicam. Referindo-se à mútua restrição objetiva entre direito e dever, FLICKINGER adverte: “ora, a esse mecanismo deve-se, entre outras, a legitimidade restrita do Estado de Direito quando de sua tendência em intervir na Sociedade Civil; por outro lado, a capacidade da Sociedade Civil de transferir os efeitos negativos de sua economia privada para o Estado, leva à socialização dos custos, reservando os lucros às vias privadas" (1989, p. 38).

Quanto à sua estrutura, a Eticidade apresenta a família enquanto a primeira esfera. Hegel afirma que,

Enquanto substancialidade imediata do espírito, a família se determina por sua unidade sentida, o amor. De acordo com isso, se tem nessa unidade, enquanto 
unidade da essencialidade que é em e por si, a autoconsciência da própria individualidade, e não está nela como pessoa, senão como membro (HEGEL, 1988, p. $237, \S 158)$.

Nesta passagem Hegel deixa claro que na família o indivíduo não é somente uma 'pessoa' e nem somente um 'sujeito', mas um membro. A família representa a primeira instituição social, pois a ideia ética não foi ainda mediada integralmente. É o momento da Eticidade natural em que o indivíduo sai de sua subjetividade e se objetiva no outro, tornandose membro a partir dessa unidade.

Hegel seguirá o texto fazendo uma 'radiografia' perfeita da instituição familiar, do casamento como a relação ética imediata, da propriedade familiar, da educação dos filhos e por fim, da dissolução da família. A unidade familiar não é ainda o modelo de unidade ética pretendido por Hegel. A forma familiar de sociabilidade apresenta-se ainda inadequada por impossibilitar o livre desenvolvimento dos seus momentos. Há, portanto, a necessidade de recorrer à outra esfera (Sociedade Civil) que surgirá no momento do relacionamento das famílias entre si como pessoas. A família mostra a sua limitação, pois não pode dar garantias do princípio da pessoa jurídica (direito). A família não consegue configurar o todo social em um grau de sociabilidade necessários, o que resulta no surgimento da Sociedade Civil.

A Sociedade Civil $^{4}$ representa o reino do poder na qual a força do universal coincide necessariamente com o particular, não de um modo livre, mas impondo de um modo cego as suas condições. Melhor é ver a definição do próprio HEGEL para essa esfera: “A pessoa concreta que é por si mesma um fim particular, enquanto totalidade de necessidade e mista de necessidade natural e arbítrio, é um dos princípios da sociedade civil” (1988, p. 260, § 182). Trata-se de um momento transitório da diferença que se coloca entre a família e o Estado. ROSENFIELD adverte, porém, que ao contrário do que aparentemente somos levados a crer,

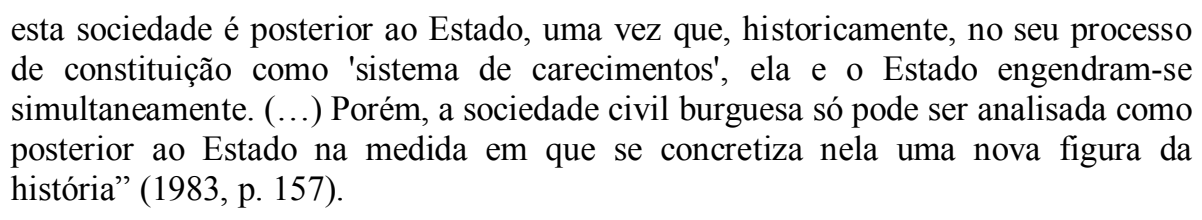

Hegel descreverá no $\$ 188$ um resumo geral da Sociedade Civil, que nos permite

\footnotetext{
${ }^{4}$ Ainda sobre a sociedade civil, temos uma interessante definição elaborada por GIANNOTTI: “A sociedade civil designava até o século XIII a trama de relações que os cidadãos, personalidades políticas mantém entre si. A noção tinha em vista, sobretudo, diferenciar as relações do cidadão com a lei das relações naturais de homem a homem. Nascendo de relações jurídicas, era natural que fosse explicada a partir do contrato e, finalmente, abrangesse todo o Estado na qualidade de corpo político (civitas). Hegel, no entanto, nela apenas vê a comunidade oriunda da ação de pessoas abstratas e isoladas, constituindo o estado exterior, onde cada um, ao perseguir seus interesses egoístas, tece uma sociabilidade que não foi assumida desde o início. Constitui, em suma, a esfera da vida social em que as personalidades jurídicas caem quando são movidas por interesses econômicos (1985, p. 14).
} 
visualizar o seu conjunto:

\begin{abstract}
A sociedade civil contém os três momentos seguintes: a) a mediação das necessidades e a satisfação do indivíduo por seu trabalho e a satisfação de necessidades de todos os demais - o sistema das necessidades; $b$ ) a realidade efetiva do universal da liberdade contida no sistema, a proteção da propriedade pela administração da justiça; c) a prevenção contra as exigências que subsiste naquele sistema e o cuidado dos interesses particulares como algo comum por meio do poder da polícia e a corporação (HEGEL, 1988, p. 266, § 188).
\end{abstract}

A Sociedade Civil parte do fato do aparecimento de pessoas independentes e reconhecidas pela sua maioridade com relação à família. Ela pode ser definida como uma espécie de 'estado exterior', 'estado de necessidades', já que nela a inter-relação se faz necessária para a realização de interesses e satisfação das necessidades. Compete então, à Sociedade Civil ser a mediação social da liberdade e a auto-regulamentação. Por este motivo Hegel irá falar das organizações, corporações, poder de polícia, da existência da lei, do código, dos tribunais, enquanto conjunto capaz de fazer essa mediação social da liberdade do indivíduo. Este, por sua vez, vai em busca da realização dos seus interesses e a satisfação das necessidades.

Antes de encerrarmos estes rápidos traços da sociedade civil é importante pontuarmos que no que diz respeito à realização da liberdade, nesta esfera a Liberdade é ainda parcial. Isso significa que a Sociedade Civil é inferior ao Estado porque este se constitui no verdadeiro fundamento dela. Hegel ainda demonstra, no contexto de transição da Sociedade Civil ao Estado, que enquanto limitada e finita, a finalidade da corporação tem sua verdade - ao igual que a separação existente na exterior ordem policial e sua identidade só relativa - na finalidade universal em e por si e em sua absoluta realidade. A esfera da Sociedade Civil passa assim ao Estado (HEGEL, 1988, p. 266, § 188).

Como a Sociedade Civil ainda permanece com um interesse particular e formal ela não pode oferecer proteção a todas as situações da inter-relação entre as pessoas que estão em busca de seus fins particulares. Surge assim, a necessidade do Estado como momento da Liberdade Absoluta. Ele, antes de ser o último estágio do desenvolvimento da eticidade "é o primeiro, dentro do qual a família se desenvolve em sociedade civil, e é a ideia mesma do Estado a que se separa nestes dois momentos" (HEGEL, 1988, p. 316, § 256). Hegel demonstra assim que, na verdade, se trata de um caminho inverso, que o Estado é o fundamento e a substância ética das demais dimensões da Eticidade, sob o qual tudo se subordina. Metodologicamente é necessário acompanhar o caminho da concretização da liberdade. 
A esfera do Estado é o lugar da concretização e da efetividade da ideia ética. Esta ideia ética toma consciência de seu próprio sujeito. "O Estado é a realidade efetiva da ideia ética, o espirito ético como vontade substancial revelada, clara para si mesma, que se pensa, se sabe e cumpre aquilo que sabe porque precisamente o sabe" (HEGEL, 1988, p. 318, § 257). É o Estado o lugar da totalidade e universalidade. A unidade substancial e o fim último Absoluto em que a liberdade alcança seu direito supremo, superior do indivíduo.

O Estado terá de ser apresentado como a unidade orgânica em que o particular, o individual e o universal se relacionam entre si de maneira tal que cada um dos momentos tenham em si os demais, numa interdependência. Cada momento deve estar integrado no todo orgânico. O Estado tem direito supremo sobre os indivíduos, pois ele é uma espécie de pensamento da cidadania concretizado nas instituições. Desse modo os indivíduos tem o dever de pôr em funcionamento o conjunto de determinações que fazem deles cidadãos. Portanto, "por ser o Estado o espírito objetivo, o indivíduo só tem objetividade, verdade e ética se fizer parte dele" (HEGEL, 1988, p. 319, § 258). O indivíduo é impensável fora do Estado pelo fato de ser uma parte que só se integra no todo, enquanto lugar da liberdade universal e objetiva. Simultaneamente, o Estado pressupõe esses indivíduos para tornar-se um Estado Liberal. A analogia que Hegel usa em sua exposição é a de um membro em relação ao corpo. Fora do Estado não há nenhuma possibilidade de vida humana livre ${ }^{5}$. O pior dos Estados é a sua inexistência, nesse sentido, Hegel concorda com Hobbes.

O princípio do Estado é a vontade, porém, Hegel se preocupa em demonstrar sua diferença com relação à tradição. Em relação à Rousseau, reconhece o mérito do filósofo francês em ter percebido a vontade como princípio do Estado, mas ao mesmo tempo indica um carência, a de ter concebido essa vontade como algo particular. Para Hegel, a liberdade não deve partir da autoconsciência individual, mas da essência da autoconsciência que é universal.

O Estado na acepção hegeliana, é tão absoluto e universal a ponto de afirmar que: "o estado é o espírito de Deus que está presente no mundo e se realiza nele com consciência (...) é a ideia mesma, esse Deus real" (HEGEL, 1988, p. 324, § 258). Essa analogia está vinculada à necessidade de dar ao Estado um caráter supremo em relação às demais esferas devido as implicações metodológicas assumidas pelo próprio Hegel. Além disso, pelo fato do filósofo temer o enfraquecimento do poder do Estado.

\footnotetext{
${ }^{5}$ Essas declarações da Filosofia do Direito, quanto ao fato de Hegel ter conferido um espécie de magnificiência ao Estado, foi senão o principal, um dos aspectos de maior crítica dos jovens hegelianos, sobretudo de Marx.
} 
Ao abordar a relação entre Estado e religião, Hegel deixa claro que a religião, na medida que se apresenta com um conteúdo verdadeiro sobre a forma da intuição, sentimento e representação, ela pode contribuir para integrar no Estado as regiões subjetivas da consciência individual. Porém, ela não deve intrometer-se nos princípios que regem a vida do Estado e a atividade científica. Conforme a interpretação de ROSENFIELD, "as relações devem subordinar-se ao Estado. (...) A organização temporal das religiões e as igrejas devem, para ter direito à existência histórica, reconhecer a superioridade do Estado que, em troca deste reconhecimento, assegura a liberdade de culto e de doutrina às diferentes correntes escolásticas ${ }^{6}$ ".

Hegel seguirá o texto tratando de fazer um exposição dos três grandes aspectos concernentes à Eticidade. São eles:

A- Direito Político Interno: neste contexto o filósofo desdobra sua argumentação em torno da constituição de um povo, seu significado e formação. Aqui pode ser destacada a ideia de que a constituição de um povo depende do modo e da cultura de sua autoconsciência. Em seguida faz uma exposição sobre o poder do Príncipe como o integrador dos três momentos do Estado: universalidade, particularidade e a decisão última. Expõe ainda sobre o processo de aquisição desse poder. Acaba reconhecendo e identificando a imediaticidade medita do espírito com a naturalidade do Príncipe, através do nascimento (hereditariedade). Essa é realmente uma parte que gera uma certa controvérsia e que não será poupada na crítica dos jovens hegelianos à obra. Vale ressaltar que a Crítica à Filosofia do Direito de Hegel elaborada por Marx dirige-se exatamente à parte do Direito Político Interno. Também nessa esfera Hegel discute sobre o poder governativo (corporações), o poder legislativo e sobre a soberania exterior.

B- Direito Político Externo: Hegel trata aqui do direito internacional, da relação entre um Estado e os outros.

C- A História Universal: expondo as diferenças entre os mundos: oriental, grego, romano, germânico, Hegel encerra sua obra com a pretensão de demonstrar que a História Universal é o elemento onde existe o Espírito Universal. A história universal é a realidade espiritual em toda extensão de sua interioridade e de sua exterioridade. A história é o terceiro momento do Estado e assim, a culminação do espírito objetivo e a transição ao Espírito Absoluto.

Através destas rápidas observações sobre a obra Filosofia do Direito de Hegel procuramos enfatizar que o caminho adotado pelo autor foi de seguir fielmente o método por

${ }^{6}$ ROSENFIELD, D. Política e Liberdade em Hegel. São Paulo: Editora Brasiliense, 1983, p. 230. 
ele abordado, respeitando uma coerência interna de seu sistema e buscando levar a cabo o princípio pressuposto da liberdade universal. Aliás, esse princípio está inserido em cada obra e pretende demonstrar-se objetivamente na Filosofia do Direito, enquanto expressão da Realphilosophie. Contudo, como procuramos demonstrar, há ali um oculto pressuposto do liberalismo na medida em que a moralidade será submetida à legalidade. Isto porém, não ofusca a riqueza teórica da obra que, segundo FLICKINGER, apresenta "um implícito potencial crítico do lado avesso desta reconstrução filosófica da sociedade liberal-moderna (...) precisamente porque Hegel, desde os primeiros passos, baseia sua filosofia política nos princípios do liberalismo" (1989, p. 38).

Marx pretenderá com sua crítica, justamente o tópico sobre o Direito Público Interno da Filosofia do Direito de Hegel, tentando demonstrar os limites do modelo hegeliano na sua pretensão de dar continuidade ao projeto de liberdade universal. Alguns desses aspectos tentaremos trazer nas páginas seguintes.

\title{
MARX E A SUA 'CRÍTICA À FILOSOFIA DO DIREITO DE HEGEL' (1943).
}

A relação teórica de Marx com Hegel é uma das mais curiosas e interessantes registradas ao longo de toda a história da filosofia, caracterizada, basicamente, pela crítica e apropriação de tal filosofia. Marx iniciara seus estudos de Hegel com a chamada 'juventude hegeliana ou esquerda hegeliana'. Nesse caloroso debate, Marx apresenta uma postura um tanto ponderada com relação a Hegel, buscando absorver as críticas de seus colegas, mas com certas precauções e respeito para com tal filosofia. Desde sua Tese de Doutoramento ${ }^{7}$ Marx apresenta indícios de sua discordância e distanciamento em relação à interpretação da filosofia hegeliana feita por alguns de seus colegas. Sobre estes dirá:

\begin{abstract}
estavam realmente tão comovidos pela ciência recém assimilada que se entregaram a mesma com confiança ingênua e acrítica: quão pouca consciência, aceitar uma intenção oculta frente a investigação do mestre. (...) Com isso, o que fazem de melhor é levantar sobre si mesmos a suspeita de não haver trabalhado seriamente antes, e combatem sua própria posição anterior, atribuindo-a a Hegel (HEGEL, 1988, p. 85-6).
\end{abstract}

Nestes caminhos e descaminhos críticos de Marx com os jovens hegelianos com relação à interpretação da filosofia do 'pai intelectual' é que surge a primeira grande obra de Marx que marca uma posição e recepção crítica de Hegel. A 'Crítica da Filosofia do Direito de Hegel', embora não apresente uma organização e sistematização, cuja redação ocorre nos meses de março e agosto de 1843 e sua publicação somente em 1927, dirige-se a concepção

\footnotetext{
${ }^{7} \mathrm{~A}$ Tese de Doutoramento trata da "Diferença entre a Filosofia Natural de Demócrito e Epicuro" (1939-41).
} 
do direito do Estado burguês. A metodologia adotada por Marx para a crítica consiste em destacar e comentar os parágrafos sobre o Direito Político Interno ( $\S$ 261-313) presente no âmbito da Moralidade Objetiva ${ }^{8}$ ou Eticidade da Filosofia do Direito. Refere-se portanto, somente ao capítulo que trata das determinações jurídicas do Estado Burguês. Contudo, muitas são as controvérsias quanto a interpretação dessa crítica de Marx.

Uma leitura parcial do texto parece apresentar Marx anunciando uma renúncia a todo o hegelianismo. O leitor apressado pode ter a impressão de que Marx está por negar a coerência sistemática da filosofia política hegeliana com relação à continuidade do projeto de autonomia e Liberdade Universal que tanto fora defendida por Hegel em suas obras anteriores. Estaria Marx pretendendo dar uma conotação 'materialista', opondo-se assim, ao idealismo hegeliano presente nessa estruturação. Contudo, o respeito implícito de Marx para com a Filosofia do Direito, quanto às contradições do Direito Civil e da Sociedade, parecem impossibilitar uma interpretação desse teor. Além do que, "do ponto de vista em que se encontra o pensamento de Marx, ainda não de todo liberto da interpretação dos 'jovens hegelianos' parece-me duvidoso, ou, pior ainda, perigoso e nivelador aceitar uma tal sobrecarga ideológica à sua teoria" (FLICKINGER, 1986, p. 51).

Para visualizar a crítica de Marx é importante retomar o que já dissemos anteriormente. Hegel, na Filosofia do Direito, se debruça sobre o problema de encontrar um mecanismo condicionador do direito moderno, capaz de garantir a conciliação entre os direitos liberais das pessoas e seus deveres. Busca resolver o impasse de como garantir a unidade entre a vontade pessoal e ordem jurídica objetiva sem negar a privacidade de ambas. O caminho metodológico por ele adotado o obrigará a propôr uma razão que legitime o Estado como garantia de conciliação entre a liberdade universal e a particular. Desse modo, o Estado só poderia manter esse princípio de liberdade se respeitasse a redução das obrigações individuais a respeito das estruturas e deveres jurídicos. O direito, nesta perspectiva, deve suprassumir todas as esferas (moralidade), porque só assim será possível garantir a radicalidade da ideia da liberdade.

A limitação mútua entre direitos e deveres acaba levando inconscientemente a Filosofia do Direito a desenhar o caminho da ideologia do Liberalismo. Consequentemente o Estado, lugar da demonstração objetiva das condições de realização da Liberdade, aparecerá como uma ordem à sociedade. A sociedade (Família, Sociedade Civil) torna-se assim, o

${ }^{8}$ FLICKINGER prefere a tradução do termo Sittlichkeit por moralidade objetiva (FLICKINGER, 1986, p. 176 nota 58). 
princípio imanente do direito. É esta solução dada por Hegel às contradições entre o interesse particular e universal que Marx não aceitará nesta crítica.

Ao iniciar sua análise Marx tece um comentário sobre o $§$ 261, no qual Hegel apresenta o Estado como uma necessidade externa frente as esferas do direito e do bem-estar privados, da família e sociedade civil. O Estado é apresentado como o poder superior em que as leis e tudo mais estão subordinados, a fim de garantir a liberdade universal. Marx irá discordar da estratégia teórica hegeliana, denunciando aquilo que ele chama 'o predomínio da ideia teórica sobre as estruturas reais da sociedade' (família, sociedade civil). Ele se posiciona contrariamente à subordinação absoluta das esferas da sociedade sob o Estado. Sobre isto, afirma:

\begin{abstract}
Entende-se exclusivamente por 'necessidade externa' o fato de as leis e os interesses da família e da sociedade deverem ceder, em caso de choque, perante as leis e os interesses do Estado, de aqueles lhe estarem subordinados e da sua existência depender do Estado. (...) Hegel estabelece aqui uma antinomia não resolvida. Por um lado, o Estado é necessidade externa, por outro é um fim imanente. A unidade do fim universal último do Estado com o interesse particular dos indivíduos deve consistir no fato dos seus deveres e direitos relativamente ao Estado serem idênticos (MARX, 1983, p. 8-9).
\end{abstract}

Aparece como certa, aos olhos de Marx, a subordinação das esferas da comunidade sob a esfera universal e política do Estado.

Trazendo algumas das passagens principais da crítica de Marx, avançamos para o $\S 262$. Hegel é criticado nesse contexto por ter dividido a ideia real, o Espirito a partir de duas esferas ideais do seu conceito que seriam a família e a sociedade civil. O estado mediatiza-se na família e sociedade civil arbitrariamente e por força do destino. A família e a sociedade civil são concebidas como esferas ideais da finitude do Estado, "aparecem como um obscuro fundo natural em que se projeta a luz do Estado (...). Nessa passagem surge claramente o misticismo lógico panteísta” (MARX, 1983, p. 10).

Para Marx, Hegel estaria pressupondo o real (família, sociedade civil) como uma esfera ideal, um fundamento abstrato do conceito (Estado). "A realidade não é expressa exatamente como é, mas sim como uma realidade diferente. (...) A relação real da família e da sociedade civil com o Estado é concebida como sua atividade interior imaginária" (Marx, 1983, p. 11). Não é pacífica, para Marx, a forma hegeliana necessária e lógica que faz todas as determinações sociais determinar-se nesse absoluto - o Estado. Para FLICKINGER, “a questão de Marx, quanto ao 'idealismo' de Hegel referia-se, portanto, sobretudo ao problema do Estado, dirigindo-se em sua crítica, em primeira linha, contra a suposta conciliação das contradições referidas pelo poder do Estado de Direito" (1986, p. 52). 
A pretensão marxiana é de possibilitar descobrir o real nas determinações hegelianas, já que segundo ele, a ideia, ao ser subjetivada, faz dos sujeitos reais (Família e Sociedade Civil) transformarem-se em momentos subjetivos da ideia. Então, o pensador conclui que "as frases de Hegel deveriam ser: a família e a sociedade civil são parte do Estado. (...) Os cidadãos são membros da família e da sociedade civil” (MARX, 1983, p. 12). Ou seja, deveria ser uma exposição em sua ordem direta e indireta e abstratamente como a apresenta Hegel.

Inúmeras são as passagens do texto marxiano que revelam seu descontentamento irônico com relação ao predomínio da ideia teórica sobre as estruturas reais da sociedade (família e sociedade civil). É uma crítica ao caminho escolhido por Hegel, de propôr uma razão que legitime o Estado enquanto garantia da liberdade universal, sem negar a liberdade particular dos membros da Sociedade Civil. Marx parece não levar em conta aqui a estratégia metodológica de Hegel de "introduzir a validade objetiva da ideia da liberdade universal enquanto 'deus ex machina', manifestando na subordinação absoluta das esferas da comunidade sob a esfera pública do Estado" (FLICKINGER, 1986, p. 53). Ou seja, de ver nessa apresentação indireta e 'abstrata' um modelo coerente àquele apresentado por seu pai intelectual.

Podemos visualizar uma intensa insistência da abordagem marxiana em mostrar a necessidade de inverter as construções hegelianas 'vazias e abstratas' produzidas pela subordinação da realidade sob os conceitos. Há uma preocupação em descobrir os fundamentos concretos desta sociedade, enquanto algo que foi esquecido ou escamoteado. Encontramos na 'Crítica da Filosofia do Direito de Hegel' muitas reflexões sobre este tópico: “a constituição política é o organismo do Estado, ou o organismo do Estado é a constituição política?" (MARX, 1983, p. 17). Ainda, “o conteúdo, a determinação real, surge-nos como formal; e a determinação formal absolutamente abstrata aparece como conteúdo concreto" (MARX, 1983, p. 26). Seguida por: “O momento filosófico não é a lógica do objeto, mas sim o objeto da lógica. A lógica não serve para justificar o Estado; pelo contrário, é o Estado que serve para justificar a lógica" (MARX, 1983, p. 26-7). Aqui Marx contrapõe-se à aparente supremacia da lógica hegeliana sobre a Filosofia do Direito. E complementará essa ideia com outra reflexão significativa: "em Hegel, a causa da constituição é a lógica abstrata e não o conceito de Estado. Em vez do conteúdo de constituição, temos a constituição do conceito. $\mathrm{O}$ pensamento não se rege pela natureza do Estado; é este que se rege por um pensamento já completamente elaborado" (MARX, 1983, p. 29).

Todo esse conjunto de observações com relação à necessidade de transformar o ideal 
em real, pode ser visualizado numa perspectiva de conjunto mais amplo das intenções de Marx. Trata-se muito mais de um estágio de indefinição no qual o pensador se encontra, que propriamente uma ruptura com a filosofia hegeliana. Acolhe, por um lado, as críticas dos jovens hegelianos, sobretudo de Feuerbach, e por outro, busca compreender a filosofia sistemática de seu pai intelectual. Ao inves de um rompimento com Hegel, Marx apresenta um impasse teórico nessa obra de 1843. Está, na verdade, preocupado em buscar uma teoria que consiga maior unidade de apresentação crítica ${ }^{9}$ Quanto ao Estado, o raciocínio mais importante de Marx parece-nos o de ter reconhecido na Família e na Sociedade Civil apenas os fundamentos ideológicos do Estado. Neste diagnóstico, o Estado liberal acaba não tendo legitimidade para intervir nesses dois setores. Haveria uma lacuna ou uma relação mal resolvida entre o Estado e a Sociedade.

O enfoque posteriormente criticado por Marx é o do poder do Soberano, bem como, a forma (hereditária) com que Hegel expõe a constituição do Príncipe. Marx segue demonstrando uma interpretação do texto hegeliano. Aqui continuam as acusações quanto a mistificação hegeliana. O poder Soberano é visto por Hegel como um ato absoluto de autodeterminação entre a vontade real e individual. Para Marx, porém, o Estado, ao negar a efetividade da sociedade (Família, Sociedade Civil), existe apenas como uma necessidade externa, como uma ideia. Ele se transforma numa substância cega e inconsciente. Assim observa Marx:

Este absurdo é uma consequência de Hegel considerar os assuntos e atividades do Estado de uma forma abstrata e em si, e a individualidade particular como o seu contrário. (...) Esquece que a essência da personalidade particular não é sua barba, o seu sangue ou sua natureza física abstrata, mas sim a sua qualidade social (MARX, 1983, p. 33).

A soberania é, na interpretação de Marx, apresentada como a essência do Estado, como um ser independente e objetivado. Portanto, os sujeitos são postos como momentos desta soberania "enquanto essa se transforma no Espírito objetivado dos sujeitos do Estado. (...) Hegel está interessado em apresentar o Monarca como Homem-Deus, como verdadeira encarnação da ideia" (MARX, 1983, p. 36). Marx pretende contrapor-se a esse modelo. Para

\footnotetext{
${ }^{9}$ Num contexto bem posterior à Crítica da Filosofia do Direito de Hegel, no prefácio à 'Contribuição à Crítica da Economia Política', o próprio Marx comenta o resultado das investigações da obra de 1843: “o primeiro trabalho que empreendi para esclarecer as dúvidas que me assaltavam foi uma revisão crítica da Filosofia do Direito de Hegel. (...) Nas minhas pesquisas cheguei à conclusão de que as relações jurídicas - assim como as formas de Estado - não podem ser compreendidas por si mesmas, nem pela dita evolução geral do espírito humano, inserindo-se, pelo contrário, nas condições materiais de existência de que Hegel, à semelhança dos ingleses e franceses do século XVIII, compreende o conjunto pela designação de 'sociedade civil'; por seu lado, a anatomia da sociedade civil deve ser procurada na Economia Política” (MARX, 1983, p. 24).
} 
isso, dá indícios de sua proximidade com a crítica feuerbachiana da religião. Expõe um argumento similar ao de Feuerbach, porém, nesse contexto, combatendo as determinações abstratas do Estado. Dirá:

Hegel parte do Estado e conclui que o homem é o Estado objetivado; a democracia parte do homem e conclui que o Estado é o homem objetivado. Assim como a religião não cria o homem e é o homem que cria a religião, também a constituição não cria o povo, sendo este que cria a constituição" (MARX, 1983, p. 46).

Nesta passagem Marx parece começar a efetuar um processo de aproximação e utilização da metodologia feuerbachiana que se baseara na 'tese do mundo invertido' presente na Fenomenologia do Espírito de Hegel, para denunciar a alienação religiosa ${ }^{10}$. Feuerbach mostrara que a religião é um aparecer enganador, um 'mundo invertido' e produto de uma abstração, a própria consciência humana. Através da religião, os indivíduos buscavam e realizavam sua ideia de liberdade universal fora de sua realidade concreta. Para Marx, parece se tornar necessário criticar as supostas ilusões e noções supostamente 'abstratas' e 'irreais' do Estado hegeliano.

O monarca corresponde para Hegel, no momento da vontade individual da autodeterminação. Porém, essa autodeterminação é, segundo Marx, arbitrária e não tem um fundamento real. Neste sentido, insere outros questionamentos sobre o processo de constituição do poder do soberano. "A razão do Estado, a consciência do Estado, é uma pessoa empírica única que exclui todas as outras; mas esta razão personificada, só tem conteúdo com abstração 'Eu quero', L'Etat c'est moi” (MARX, 1983, p. 41). Marx parece querer expor Hegel como um autor que legitima e coisifica as relações sociais sob as determinações de um poder absoluto que nega a liberdade do indivíduo. Para enfatizar esta ideia procura demonstrar a diferença entre Monarquia e Democracia.

Com muita ironia, Marx apresenta o processo de aquisição do poder do Príncipe como um processo extremamente arbitrário e despótico. Dirá: “o nascimento determina a qualidade do monarca, tal como determina a qualidade do gado. Hegel demonstrou que o Monarca deve nascer - coisa de que ninguém duvida - mas não demonstrou que o nascimento faz o Monarca. O nascimento de um homem como Monarca é tanto uma verdade metafísica como a Imaculada Concepção de Maria, mãe de Deus" (MARX, 1983, p. 52). Marx parece desconsiderar aqui o fato de Hegel ter exposto amplamente que o poder do Estado, além do poder do Príncipe, é constituído pelo poder Governativo e Legislativo, admitindo o

\footnotetext{
${ }^{10} \mathrm{O}$ texto de Marx que deixa mais explícita a aproximação teórica do pensador com Feuerbach é a 'Introdução à Crítica da Filosofia do Direito de Hegel'. Texto escrito posteriormente à 'Crítica da Filosofia do Direito'.
} 
envolvimento de um conjunto da Sociedade Civil preparada para o cargo. Não percebe a estratégia metodológica hegeliana, e então considera a Soberania como algo aparentemente fundamentada na ideia de vontade livre universal, mas que na verdade acaba rompendo com esse pressuposto, através da instituição arbitrária do poder do Príncipe.

Ainda sobre a 'Crítica à Filosofia do Direito de Hegel' podemos trazer as observações contundentes de Marx a respeito da burocracia. Momento em que a reflexão se direciona em apontar até que ponto da burocracia (corporações) podem interferir na vida do Estado. $\mathrm{O}$ problema e as contradições inerentes à burocratização da política, cumprindo um papel de formalismo no Estado:

A burocracia é o Estado enquanto formalismo, (...) é evidente que a burocracia é o
conjunto de ilusões práticas, ou seja, é a ilusão do Estado. O espírito burocrático é
um espírito totalmente jesuítico, teológico. Os burocratas são os jesuítas e os
teólogos do Estado. (...) A burocracia constitui o Estado imaginário, paralelo ao
Estado real, é o espiritualismo do Estado" (MARX, 1983, p. 73).

Ademais, Marx continuará criticando a separação entre determinações universais (Estado) das esferas particulares (família, sociedade civil) que serão mediadas por um poder governativo que não sabemos se é universal ou particular. Marx também utiliza uma metáfora para ironizar essa separação: "é a história do marido e da mulher que discutem e do médico que quer mediar entre ambos, tanto da mulher que quer interpor-se em seguida entre o médico e o seu marido e este entre a sua mulher e o médico" (MARX, 1983, p. 135). Segundo Marx, a mediação é exigida constantemente na filosofia de Hegel para resolver a contradição por ele criada, mas que na verdade, mais confunde e deixa indefinidos os termos mediados. Quanto ao morgadio e a propriedade privada, demonstra com elas se tornam, na filosofia hegeliana, uma determinação substancial, livre e inalienável. "O morgadio não é, contrariamente ao que Hegel afirma, 'um obstáculo à liberdade do direito privado', mas antes a 'liberdade do direito privado' que se libertou de todos os obstáculos sociais e morais" (MARX, 1983, p. 154). De maneira geral, parece-nos estes alguns dos principais núcleos da crítica de Marx a Filosofia do Direito de Hegel presentes na 'Crítica à Filosofia do Direito de Hegel'.

\section{CONSIDERAÇÕES FINAIS}

Uma avaliação geral da 'Crítica da Filosofia do Direito de Hegel' permite-nos dizer que se trata de um conjunto de referências e comentários das partes referidas da Filosofia do Direito de Hegel, por um jovem pensador que está discernindo sua própria postura medológico-filosófica. Primeiramente, podemos dizer que, buscando o homem concreto, autônomo, que estava supostamente perdido nas determinações do Estado, Marx parece não 
ter percebido o papel metodológico determinado pela ideia pressuposta da liberdade universal presente na obra criticada. O caminho interpretativo adotado por ele, bem como, as influências dos jovens hegelianos, parece não permitir que o jovem pensador percebesse a limitação mútua entre direitos e deveres, o que, ao mesmo tempo, implicava em fazer com que o Estado reduzisse ao máximo as obrigações individuais com relação às estruturas e deveres jurídicos. Sem desmerecer a capacidade do jovem Marx, FLICKINGER considera que

criticando Hegel por causa de sua subordinação da realidade sob a lógica da ideia da vontade livre, ou seja, sob as necessidades da racionalidade do conceito pressuposto, Marx só descreveu de modo objetivo e sem dar-se conta disso, o método de apresentação hegeliano que objetivava revelar as condições concretas da realização da liberdade universal (1986, p. 56).

O pensador de Trier parece não perceber que a estratégia hegeliana tem em vista preservar a coerência com o princípio pressuposto (liberdade universal) e que por essa razão, tal teoria não se baseia no uso meramente afirmativo da ideia de liberdade.

Por outro lado, em sua crítica Marx consegue bons resultados quanto à descrição das dificuldades de Hegel em relação a antinomia entre o poder do direito do Estado e do indivíduo. O seu interesse dirige-se na descoberta dos fundamentos concretos da sociedade que estavam desaparecidos no conjunto conceitual hegeliano. Porém, ele não aceita a solução hegeliana e nem sua capacidade crítica. Somente consegue ver na filosofia política de Hegel uma descrição adequada da mediação abstrata da sociedade liberal.

Apesar de uma exposição geral dos tópicos apresentados, o que procuramos não perder de vista neste trabalho, foram dois aspectos em especial: a) se por um lado a estratégia hegeliana da dupla limitação entre direito e dever é coerente com o pressuposto do qual o pensador não abre mão que é a liberdade universal, por outro, num sentido moral, ela acaba por gerar conflitos e lacunas na medida em que o direito não consegue responder a muitos aspectos da complexidade social, e, portanto, servirá de fundamento para um Estado liberal; b) se a crítica de Marx à Filosofia do Direito de Hegel, por um lado, não leva em conta a compreensão da estratégia metodológica hegeliana da limitação entre moral e direito como uma continuidade do projeto de levar a sua radicalidade a ideia da liberdade universal, por outro lado, ela representa um primeiro passo de um caminho importante do início do distanciamento de Marx com relação às armadilhas interpretativas do jovens hegelianos que buscavam reduzir a Filosofia do Direito de Hegel a uma legitimação explícita do Estado Prussiano. Passo esse que inaugura uma nova matriz teórica que caminha ao lado da filosofia 
de Hegel.

\section{REFERÊNCIAS}

FLICKINGER, H-G. A legalidade da moral: considerações em torno da dupla moralidade da sociedade liberal. Rev. Véritas, Porto Alegre, v. 40, no 157, p. 15-26, março 1995.

Hegel: a lógica ambígua da Revolução Francesa. In:. RIBEIRO, Renato Janine (Org.) Sombra e Luzes. São Paulo: EDUSP, 1989.

Marx e Hegel: o porão de uma filosofia social. Porto Alegre: L \& $\mathrm{PM} / \mathrm{CNPq}, 1986$.

FREDERICO, C. O jovem Marx - as origens do ser social. São Paulo: Zahar, 1995.

GIANNOTTI, J. A. Origens da dialética do trabalho. São Paulo: L\&PM editores, 1985.

HEGEL, G. W. F. Fenomenologia do Espírito. 2a Ed. Petrópolis: vozes, 1992.

. Principios de la Filosofia del Derecho. Barcelona: Edhasa, 1988.

MARX, K. Crítica à Filosofia do Direito de Hegel. Lisboa: Editora presença/Martins Fontes, 1983.

. Diferencia entre la filosofia natural Democrítea y la Epicúrea. In:. Escritos sobre Epicuro. Barcelona: Editora Crítica, 1988.

Contribuições à crítica da Economia Política. São Paulo: Martins Fontes, 1983.

ROSENFIELD, D. Introdução ao pensamento político de Hegel. São Paulo: Ática, 1993. . Política e Liberdade em Hegel. São Paulo: Editora Brasiliense, 1983.

WEBER, T. Hegel: Liberdade, Estado e História. Petrópolis: Vozes, 1993. 